\title{
Fragmentos de uma
}

\section{«analítica» da midiatização}

\author{
ANTONIO FAUSTO NETO*
}

\section{RESUMO}

O texto dispõe-se a refletir sobre o conceito de «analítica da midiatização», tomando como referência a evolução da «sociedade dos meios» para «sociedade midiatizada». A partir de elaborações sobre o fenômeno da midiatização, descreve a sua organização, mas detêm-se no seu funcionamento. Vincula a emergência destas novas «estratégias interpretativas» à crescente autonomia do campo das mídias que impõe, de sua parte, transformações nos «contratos» e nos vínculos entre estruturas de produção e recepção de discursos midiáticos. Finalmente, propõe a compreensão dessa enquanto um conceito associado às práticas que se estruturam e desenvolvem a partir de operações de sentido engendradas no âmbito enunciativo da cultura midiática.

Palavras-chave: midiatização, analítica da midiatização, sentido, leitura, incompletude

\section{ABSTRACT}

The text intends, through a dialogue with authors, to reflect about the concept of «analytics of the mediatization», taking the evolution from the "society of means» to the «mediatic society» as reference. It ties the emergency of this new «interpretative strategies» to the increasing autonomy of the media field, that imposes, from its part, transformation in the "contracts» and in the bonds between the production structures and the reception of mediatic discourses. Finally, it proposes the comprehension of this «analytics» as a concept associated to the practices that are structured and developed from operations of sense engendered in the enunciative ambit of the mediatic culture. Key words: mediatization, analytics of mediatization, meaning, reading, incompleteness

\footnotetext{
* Professor titular do Programa de PósGraduação em Ciências da Comunicação da Unisinos(RS).

afaust@terra.com.br
} 
$\mathrm{O}$ EXERCÍCIO DE CONSTRUÇÃo de algumas notas sobre a «analítica da midiatização» exige, metodologicamente, como um breve aclaramento preliminar, que sejam apontadas algumas observações sobre o conceito de midiatização. Tal exigência situa-se no contexto das preocupações que visam evitar que esta noção fique - a exemplo de outros conceitos - flutuando como um termo destituído de necessária problematização, restando, como «palavra vazia», sem receber os necessários tensionamentos teóricos. Nestas condições, e levando em conta os objetivos deste artigo, destacamos algumas observações que chamam atenção para o fato de que o exercício teórico de construção do conceito situa-se imbricado na própria processualidade do fenômeno.

Aclarando: a midiatização resulta da evolução de processos midiáticos que se instauram nas sociedades industriais, tema eleito em reflexões analíticas de autores feitas nas últimas décadas e que chamam atenção para os modos de estruturação e funcionamento dos meios nas dinâmicas sociais e simbólicas.

Em suas reflexões sobre as Conseqüências da modernidade, Giddens (1991) define os meios de comunicação, e seus peritos, como espécies de "portas de acesso" no sentido de possibilitar que a sociedade construa vínculos, estabelecendo relações com os "sistemas abstratos". Explicando o conceito, diz que as mídias, através de suas ações e dos seus "peritos", cuidam de traduzir para os indivíduos conceitos e problemáticas que, parecendo distante, necessitam do «trabalho mediador», como lugar que venha instituir elos de confiança e de segurança para os indivíduos. De alguma forma, na tese do sociólogo britânico, já estão presentes ainda que de forma indireta, os conceitos como os de redução de complexidades, regulação interativa e o de redução de riscos, que aqui são apresentados.

Num contexto mais ou menos parecido, Rodrigues, em suas elaborações sobre os campos sociais como lugar de produção das práticas, aponta para a singularidade que representa o campo das mídias enquanto um lugar cuja organização e funcionamento incidiram sobre os modos de se viver a experiência e as interações sociais, hoje. Diz, grosso modo, que em tempos contemporâneos, a experiência passa a ser redesenhada pela presença de tecnologias e seus protocolos comunicacionais, atribuindo ao campo que organiza tais práticas um certo papel regulatório (Rodrigues, 2000). Ou seja, a vida e dinâmicas dos diferentes campos são atravessadas, ou mediadas, pela tarefa organizadora tecno-simbólica de novas interações realizadas pelo campo das mídias.

No âmbito dos estudos comunicacionais latino-americanos, essas preocupações aparecem com outra roupagem. Na transição dos anos 70 para a década de 80 , a ação das mídias, e sua centralidade na vida cultural e 
política da América Latina, era também destacada, segundo argumentos que reconheciam o seu "poder» e os «efeitos», associados, ou em contato, com dinâmicas de outras práticas. Sublinhava-se que a importância estratégica das mídias somente poderia ser levada em conta e compreendida, se articulada com outras práticas sociais, cujas dinâmicas instalavam e estruturavam fortemente os contextos e a temporalidade das instituições e dos indivíduos (Martín-Barbero, 1997).

As elaborações de Giddens, Rodrigues e Barbero sobre a ação das mídias estão situadas numa processualidade em que se problematiza a existência desta modalidade de comunicação, distinta de construções nitidamente funcionais. Mobilizam modelos teóricos e analíticos que vêm fornecer novos quadros explicativos sobre a sociedade e, de modo particular, o status das práticas midiáticas junto aos processos de organização e de estruturação de dinâmicas sócio-simbólicas. Entretanto, não visualizam ainda o que viria a ser a midiatização. Expliquemos: chamam atenção para uma certa centralidade das mídias, mas enquanto um «lugar mediador» na medida em que estas se colocam como um ponto de articulação entre partes da sociedade, dependendo num grau maior ou menor, de outras dinâmicas de campos e de suas práticas sociais. Historicamente, entende-se que tal dinâmica concederia à existência dos meios uma espécie de «ação representacional». Circunstância em que co-dividiriam, com práticas de outros campos sociais, a tarefa de produção de inteligibilidades. Neste contexto de processualidades, as reflexões de Matta (1999) já esboçam a visualização dos horizontes emergentes da midiatização Ao elaborar distinções entre a "cultura massiva» e a «cultura midiática», a partir da evolução dos modos de funcionamento desta segunda cultura, aponta para a existência de um novo «sujeito». Referindo-se às tecnologias e ações institucionais que geram novos processos interacionais, chama atenção para a importância dos meios e a centralidade do seu papel na análise cultural, mas já não em seu caráter de transportadores de algum sentido (...) ou como espaços de interação entre produtores e receptores, mas como marca, modelo, matriz, racionalidade produtora e organizadora de sentido (Matta, 1999: 80, 91). Indica pistas para a compreensão do que viria a ser tal «analítica» da mídia, ao apontar para a conversão que sofre a tecnologia em um novo dispositivo de leitura e de organização de sentidos. Mas, a compreensão deste objeto somente se explicita, com vigor, pelos «efeitos de ruptura» entre a «visão representacional» e as hipóteses sobre a midiatização, ao atribuir-lhe um outro tipo de protagonismo atravessado por uma complexidade que não estaria situada apenas nas tecnologias, em si, mas na sua conversão na forma de meios, segundo dinâmicas de operações de sentido, no âmbito das práticas sociais. 


\section{EMERGÊNCIA DA MIDIATIZAÇÃO}

A convergência de fatores sócio-tecnológicos, disseminados na sociedade segundo lógicas de ofertas e de usos sociais produziu, sobretudo nas três últimas décadas, profundas e complexas alterações na constituição societária, nas suas formas de vida, e suas interações. Ocorre a disseminação de novos protocolos técnicos em toda extensão da organização social, e de intensificação de processos que vão transformando tecnologias em meios de produção, circulação e recepção de discursos. Já não se trata mais de reconhecer a centralidade dos meios na tarefa de organização de processos interacionais entre os campos sociais, mas de constatar que a constituição e o funcionamento da sociedade - de suas práticas, lógicas e esquemas de codificação - estão atravessados e permeados por pressupostos e lógicas do que se denominaria a «cultura da mídia». Sua existência não se constitui fenômeno auxiliar, na medida em que as práticas sociais, os processos interacionais e a própria organização social, se fazem tomando como referência o modo de existência desta cultura, suas lógicas e suas operações.

Teóricos e estudiosos elegem esta nova ordem comunicacional, segundo perspectivas distintas, chamando atenção para uma problemática na qual as mídias deixam de ser uma «variável dependente», um «subsistema a serviço de uma ação social organizada», conforme situam os funcionalistas. Ou ainda «aparelhos», «instrumentos de poder», como preferiam as percepções estruturais. Conceitos novos aparecem para tornar mais inteligível este fenômeno. Sodré define-o como uma nova forma de mediação específica, instaurando um novo bios - o bios midiático - sobre a qual repousa uma nova forma de tecno-interação (Sodré, 2004). Gomes fala de uma nova ambiência cujos processos midiáticos viriam a se constituir em novos operadores da inteligibilidade social (Gomes, 2006). Braga identifica o papel que têm as reformulações sóciotecnológicas na passagem dos processos midiáticos gerando "processualidade interacional de referência” (Braga, 2006). Verón sublinha o status das mídias mesclando-se em todos os aspectos significativos do funcionamento social, mediante complexas interações entre mídias, instituições e indivíduos, daí resultando processos de afetações não-lineares (Verón, 1998) engendradas por práticas discursivas. O eixo que atravessa tais formulações é o fato das mesmas entenderem que as mídias deixaram de ser apenas instrumentos a serviço da organização do processo de interação dos demais campos, e se converteram numa realidade mais complexa em torno da qual se constituiria uma nova ambiência, novas formas de vida, e interações sociais atravessadas por novas modalidades do "trabalho de sentido». Neste contexto, as mídias não só se afetam entre si, se inter-determinando, pelas manifestações de suas operações, mas também outras práticas sociais, no âmago do seu próprio funcionamento. 
A ênfase das operações de sentido da midiatização sobre a organização social e a expansão da autonomia do campo das mídias, estaria relacionada com fatores históricos, especialmente àqueles que geram o funcionamento da cultura no âmbito da sociedade contemporânea. A chamada crise dos grandes relatos produz uma outra que é a da inexistência de legitimidade de um discurso que pudesse sozinho articular fundamentos que viessem a ser aceitos pelos campos sociais. Tal fato instaura novos regimes de discursividades, cuja dinâmica é caracterizada por uma equivalência geral de todos os discursos e uma certa autonomia dos seus jogos; cada um com suas regras especificas, constituindo um tipo de universo relativamente fechado (Verón, 1997), fazendo aparecer uma realidade destituída de pólos e de discursos centrais. Este contexto parece preceder o que viria a ser a emergência das práticas midiáticas como um lugar autônomo que viria a se colocar como um dispositivo organizador das interações dos campos, a partir de suas competências (as mídias como lugar mediador de outros discursos). E também, a própria midiatização, cuja dinâmica trataria de se impor como uma nova organização sócio-simbólica, espécie de nova dinâmica em cujas lógicas e fundamentos se estruturariam a centralidade da emergente e complexa organização social, segundo a racionalidade de um «programa tecno-discursivo», com as tecnologias sendo convertidas em meios, segundo lógicas diferentes de práticas sociais.

Uma designação econômica para diferenciar a «sociedade dos meios» da «sociedade da midiatização» está no fato de que na primeira as mídias estariam a serviço de uma organização de um processo interacional e sobre o qual teriam uma autonomia relativa, face à existência dos demais campos. Na segunda, a cultura midiática se converte na referência sobre a qual a estrutura sóciotécnica-discursiva se estabelece, produzindo zonas de afetação em vários níveis da organização e da dinâmica da própria sociedade. Nestas condições, as mídias seriam o lugar (...) em que no plano da sociedade global ter-se-ia o "trabalho" sobre as representações sociais (Verón, 2004). As mídias perdem este lugar de auxiliaridade e passam a se constituir uma referência engendradora no modo de ser da própria sociedade, e nos processos e interação entre as instituições e os atores sociais. A expansão da midiatização como um ambiente, com tecnologias elegendo novas formas de vida, com as interações sendo afetadas e/ou configuradas por novas estratégias e modos de organização, colocaria todos - produtores e consumidores - em uma mesma realidade, aquela de fluxos e que permitiria conhecer e reconhecer, ao mesmo tempo. Nada estaria fora das fronteiras da sua constituição, uma vez que não haveria nenhum objeto a ser representado, pois tudo estaria contido nas múltimas relações e co-determinações, a se manifestarem no modo de existência deste ambiente de fluxos e de 
envio/re-envios. Não se trata mais da «era dos meios» em si, mas de uma outra estruturada pelas próprias noções de uma realidade de comunicação midiática. Nela, são organizados e dinamizados processos que reformulam as condições de enunciar a realidade, esta não mais como um fenômeno representável pela linguagem, mas que se constitui no próprio agenciamento enunciativo dos novos modelos de interação. Ao se converter numa espécie de «sujeito» dos processos e das dinâmicas de interação social, a cultura midiática torna-se um complexo dispositivo em cujo âmbito se organiza um tipo de atividade analítica, cujas gramáticas, regras e estratégias geram ainda, por operações auto-referenciais engendradas no dispositivo, as inteligibilidades sobre as quais a sociedade estruturaria suas novas possibilidades de interpretação.

\section{«ANALÍTICA DA MIDIATIZAÇÃO»:ALGUMAS APROXIMAÇÕES}

Recapitulando, de modo rápido: procuramos, de forma sintética, apontar aspectos sobre os quais o conceito de midiatização foi se estruturando, concomitante ao desenvolvimento das transformações societárias, oriundas da instalação de novas formas de interação e resultantes da conversão de tecnologias em meios, segundo diferentes lógicas sociais. Tal providência deveria ser respondida para que pudéssemos construir alguns registros, enquanto comentários e exercícios, a respeito da «analítica da midiatização», principalmente os cuidados com o funcionamento de suas manifestações.

De forma tão somente hipotética, entende-se aqui o conceito de «analítica da midiatização» como trabalho de leitura realizado por uma modalidade de comunicação, segundo práticas que envolvem dispositivos tecno-discursivos que tomam como referência o modo de existência das lógicas e dos pressupostos da cultura midiática, se estruturam em suas próprias formas de linguagens e por meio de operações de sentido para construir realidades, na forma de textos nos quais se figuram representações sobre a realidade construída.

Entender esta «ambição» da midiatização enquanto possibilidade de ação interpretativa que se institucionaliza crescentemente, no seio das sociedades chamadas pós-industriais, implica levar em conta dois aspectos: em primeiro lugar, o processo crescente de autonomia do campo midiático e que se manifesta na própria singularização das estratégias deste universo, enquanto um novo lugar pedagógico-interpretativo. Entretanto, os processos de referenciação da realidade, estruturados em torno da lógica da midiatização, não se acantonam apenas nas fronteiras das próprias práticas midiáticas. Migram para outras práticas sociais, atravessando-as e afastando-as por operações significantes, cujo emprego é condição para que as mesmas passem a ser reconhecidas. Em segundo lugar, a compreensão que o próprio trabalho teórico tem sobre esses 
processos de autonomização e, sobretudo, dos seus efeitos, ao refletir sobre as transformações da «sociedade dos meios» na «sociedade midiatizada». No cenário da produção teórica sociológica, destaca-se a contribuição de Luhmann (2005) para elucidar tais efeitos. Em considerações para explicar as implicações das teorias sistêmicas (de segunda geração) sobre a sociedade, meditou em um livro especifico sobre as mídias, os processos que levam este sistema a constituir, por suas próprias operações, uma determinada realidade. E, ao qualificar a competência deste sistema, chama atenção para o fato de que as mídias, sendo instâncias observadoras que trabalham outras observações (leituras de outros sistemas), têm, por conta de sua própria autonomia operacional de natureza tecno-simbólica, o poder de funcionar como um dispositivo «redutor de complexidades». Ou seja, através de leis e regras próprias, estruturam práticas e rotinas segundo leituras (observações) que visam regular observações que sendo construídas em outros sistemas, devem ser organizados segundo as «leis» deste sistema observador (as mídias), como condição de sua inteligibilidade. As considerações luhmanianas, lidas dessa perspectiva, permitem aproximar a noção de «analítica» enquanto uma ação próxima daquele, por ele definido, como «redutor de complexidades». Afinal, o que é um «sistema leitor»? Um lugar operador de codificação e de classificação de um determinado objeto, segundo os fundamentos de suas próprias lógicas e operações e que visa produzir situações de inteligibilidades. Fazemos uma aproximação do conceito, aqui em discussão, com a noção de analítica, elaborada no campo terapêutico. Nele, esta noção evoca, grosso modo, um trabalho sobre o qual se estrutura o percurso de um tratamento de alguém que, demandando a incidência sobre o seu sofrimento do «ato interpretativo», faz assim emergir a existência de «um ponto de apoio» (Chemama, 2007). Situado no interior de um determinado dispositivo, esse ponto se oferecerá para que através dele, e segundo suas gramáticas, se construa um percurso que apresente possibilidades interpretativas sobre o "mal-estar» objeto da demanda. Noções como a de «redutor de complexidade» e "ponto de apoio» são, também de certa forma, idealidades a que se propõe o trabalho interpretativo das práticas da midiatização e de suas operações de sentido. Por outras palavras, o ponto de apoio edifica-se em um dispositivo, desenvolvendo uma ação sistêmica que visa produzir, a seu modo, uma ação interpretativa.

\section{FUNCIONAMENTO DA «ANALÍTICA»: ALGUMAS DESCRIÇÕES}

Convém destacar que o funcionamento do «trabalho interpretativo» de natureza midiática desenvolve-se no interior da processualidade da «sociedade dos meios» à «sociedade da midiatização». Lá, na primeira, a transformação do exercício da experiência, pela mediação de protocolos sócio-tecnico-discusivos, 
já incide sobre as próprias «políticas discursivas» dos campos sociais, roubandolhe o papel de centralidade na tarefa de enunciações dos seus próprios pontos de vista. Com a emergência das mídias, os discursos de campos sociais passam a ser enunciados segundo novas regras de inteligibilidades, e assim deslocados pelas tecnologias de comunicação para uma nova forma de ser da «esfera pública». Na segunda, como conseqüência da intensificação e da generalização das operações midiáticas de construção de práticas de sentidos, instala-se uma nova ambiência interacional, cujas práticas sociais são atravessadas por fluxos, operações e relações técnico-discursivas, constituídas por fundamentos midiáticos que, ao encerrarem em si mesmos - em suas lógicas e operações - as transações de discursos e de interações entre atores e instituições, redesenham os vínculos sociais que passam a se reger por novas «formas de contatos». Por outras palavras, os «efeitos de poder» da «analítica da midiatização» inscrevem-se na própria organização societária, colocando-se como referência para a organização discursiva e as operações de inteligibilidade das práticas sociais. Atravessam-nas, permeando suas "políticas de sentido», tanto em situação de produção como também junto àquelas sobre as quais se assentam as possibilidades do seu reconhecimento. A midiatização institui um novo «feixe de relações», engendradas em operações sobre as quais se desenvolvem novos processos de afetações entre as instituições e os atores sociais.

Examinadas essas questões, descreveremos algumas das características sobre a organização e funcionamento desta «analítica» situadas apenas no âmbito do próprio campo das mídias, tomando como referência certos aspectos relacionados com as transformações do processo de produção do discurso jornalístico. A escolha sobre tais angulações se deve ao fato de considerarmos que os discursos jornalísticos se propõem, por natureza, a realização de uma determinada tarefa «analítica» segundo «regras privadas» inerentes às suas rotinas e processos produtivos. E, ao mesmo tempo, pelo fato de que a prática jornalística reúne as «idealidades» mediadoras da mídia, comentadas acima por nossos autores. Finalmente porque traz característica da midiatização, que é o fato de se constituir progressivamente num dispositivo que goza da autonomia crescente para se apresentar como um operador de complexidades e, ainda, para construir realidades por suas próprias operações de sentido.

Segundo nossas hipóteses, as configurações desta «analítica», e de seu funcionamento, apresentam-se no universo do jornalismo e de sua prática, segundo quatro aspectos: 1) transformações da "topografia jornalística», como espaço «organizador do contato»; 2) a auto-referencialidade do processo produtivo; 3) auto-reflexividade sobre seus fundamentos teóricos; 4) transformação do status do leitor. 
Certamente, esse conjunto seria mais largo; entretanto, nossas observações empíricas nos permitem restringir observações apenas sobre esses quatro itens.

Nossa hipótese propõe que não só os registros sobre a natureza desse dispositivo, mas os argumentos sobre os fundamentos que estruturam a sua concepção, estão arrolados na própria prática discursiva jornalística. São manifestações e marcas que estão presentes no próprio funcionamento do dispositivo, que não só o estrutura, mas desenvolve modos de dizer sobre suas propriedades enquanto estratégias discursivas voltadas para o leitorado. Ou seja, o dispositivo não só anuncia a sua existência, mas chama atenção para os fundamentos e os efeitos presumidos de sua prática interpretativa. No fundo, estamos diante de uma operação enunciativa auto-referencial, na medida em que o lugar analítico chama atenção sobre o seu próprio modo de ser. Um comentário breve, sobre os quatro aspectos acima arrolados.

A) Transformações da «topografia jornalística» como espaço «organizador do contato» - Cada vez mais, jornais e revistas transformam seções em que se dirigem aos leitores em espaços nos quais relatam a organização e funcionamento da dinâmica dos seus ambientes de trabalho. A redação e outros espaços da prática e das rotinas jornalísticas são visualizados ao leitor, na forma de várias construções, cujas estratégias visam apontar para o fato de que tais ambientes não devam se constituir numa referência longínqua, ou mesmo numa abstração. Imagens são introduzidas para explicar o modo de ser da redação e suas editorias, agora transformados em novos ambientes que aparecem visualizados com a descrição do que são, como funcionam e como neles estão instalados os jornalistas: "As posições de mediadesk, a nova mesa de operações editoriais de Zero Hora" ( $\mathrm{ZH}$, Porto Alegre, 23/04/2007). É preciso visualizar este processo de trabalho, torná-lo palpável a fim de que a noção do jornal não se reduza apenas ao ato de venda e compra. Os jornalistas também são «atorizados», não como fontes indeterminadas. Referencias à sua existência aparecem na forma de imagens no corpo destes próprios textos institucionais, como é o caso da seção «Carta ao Leitor»: "Anna Paula, Karina e Adriana: o time de Veja para área de saúde e medicina" (Veja, 20/02/2007) para não só sinalizar que têm "corpo e alma», mas também para situá-los, enquanto novos tipos de "celebridade», na vitrine do próprio processo produtivo, na qual se descreve, pela eleição destes personagens, as virtudes do seu próprio trabalho. É preciso reformular o conceito desta cadeia produtiva, mostrar e descrever a configuração tecnofísico-simbólica não só como ela é. Mas o que faz e como faz e, especialmente o papel desses atores no fazer do jornal. Se essas estruturas servem para exibir os detalhes do nicho produtivo, expande-se para a própria topografia do jornal 
o esforço explicativo sobre seu modo de ser. Neste sentido, as próprias reformas feitas no projeto gráfico de um jornal tornam-se acontecimento jornalístico. Registros são apresentados em diferentes páginas e os relatos chamam atenção do leitor para os efeitos deles no próprio «contrato de leitura» que articula o vínculo entre produção/consumo da informação (Este é o seu novo Diário, $\mathrm{O}$ que muda no seu Diário de Santa Maria. Diário de Santa Maria, 19/06/2007). Certamente, poucos campos sociais exibem com tanto didatismo a «cozinha» dos seus processos produtivos como faz, atualmente, o jornalismo. O efeito de sentido dessa estratégia é, justamente, argumentar que é preciso construir um vínculo mais duradouro entre estruturas de produção e consumo do jornal, e, para tanto, é preciso tornar visível e disponível o universo do próprio processo produtivo, nele fazendo, de alguma forma, aceder o leitor.

B) Auto-referencialidade do processo produtivo - As estratégias através das quais o dispositivo da «analítica» se põe em contato com os leitores desdobramse num outro tipo de operações, e que consistem na produção de discursos auto-referenciais sobre o processo produtivo. Não se trata mais de falar para o leitor, apontá-lo a realidade construída, ou dizer que sabe ou que «soube antes», mas relatar como faz para dizer que «sabe antes...». Na apresentação desta «realidade da construção» edifica-se um novo contrato de leitura através do qual as mídias acabam sendo seu próprio objeto. Ou seja, segundo um novo modelo de enunciação posto em prática, trata-se produzir uma enunciação na qual fale de si mesma, através do que privilegia não representações de um mundo externo, mas suas próprias operações, nas quais se explicitam os fundamentos dos seus próprios processos interpretativos. A isso, poderíamos definir como discurso auto-referencial e que se caracterizaria pela chamada de atenção da sua própria existência, dos seus processos de enunciação, dos seus modos de conhecer. O bom exemplo para o que aqui se aponta é a seção «Por dentro do Globo», do jornal O Globo, do Rio de Janeiro, espécie de versão distinta do tradicional texto institucional através do qual a mídia jornalística se dirige ao leitor. Sua ênfase é falar de suas próprias operações de produção, de suas rotinas, de como trabalham os jornalistas nas coberturas que lhes são confiadas. Trata-se de uma estratégia que reúne um somatório de ações: prestação de contas (Entrevista Inédita, O Globo, 01/o9/2006); descrição do seu próprio trabalho de rotina produtiva (A hora de inventar, O Globo, 27/07/2007); ênfase sobre um discurso de auto-celebração referido às condições de uma cobertura (Visita ao submarino nuclear, O Globo, 23/09/2007); as virtudes de um próprio produto resultante do seu processo de elaboração (A viagem de uma foto, $O$ Globo, 12/o9/2007). A ênfase do trabalho analítico não está no 
que mostra, mas nos seus próprios atos, nos procedimentos desenvolvidos para mostrar o acontecimento (construído), cujos fundamentos visam produzir um discurso de auto-celebração de um modo de prática de jornalismo. Os efeitos dessas operações visam destacar a existência do «jornalismo personagem», cuja chamada de atenção destaca um contemplar sobre si mesmo, enfatizando apenas a enunciação nas quais se engendram suas performances.

C) Auto-reflexividade posta em ato - As operações discursivas, em que se assentam essas estratégias do ato analítico, trazem reflexões contíguas sobre o fazer jornalístico, uma espécie de operação auto-reflexiva na qual se teoriza sobre o ato jornalístico e seus processos de produção. São enunciações que refletem os desafios e os efeitos de um «modo de dizer», chamando atenção para as concepções do dispositivo sobre o seu trabalho, e seu processo produtivo. Quando do lançamento da Revista da Semana, seu primeiro número (03/09/2007) trouxe argumentos nos quais explicita os fundamentos de construção da noticiabilidade que orientam o seu projeto editorial:

Você tem em mãos uma revista diferente.(...) Ela é propositadamente fininha. (...) Seus textos são curtos, mas curto, aqui, não quer dizer superficial. O objeto aqui é apresentar a notícia (...) e tudo que significa no menor espaço possível. (...) Notícias na medida do seu tempo (...) Por que a Editora Abril resolveu lançar uma revista noticiosa neste cenário? A resposta é simples: alguém precisa filtrar e organizar este tsunami de informação. (...) Por isso que o slogan da Revista da Semana é «É mais informação em menos tempo. Para um novo leitor de uma nova época».

Ou seja, o seu contrato define-se por uma estratégia didática na qual aliaria concisão e seleção, processos a serem monitorados pela existência de uma estrutura mediadora - o filtro - que não só atuaria como «guardião do contato» entre estruturas produtoras e receptoras, mas também operaria como um dispositivo de seleção/interpretação de acontecimentos compatíveis com a noção de um «leitor presumido», ou seja, o consumidor instaurado pela lógica e os ventos da midiatização.

Num outro modelo de publicação, a natureza dos vínculos existentes entre revista especializada - como a Revista Pesquisa Fapesp - com seu universo de leitores, leva a própria editora da publicação a refletir de um certo modo «críticoanalítico» sobre os critérios e as definições de matérias de capa, afastando-se das estratégias que caracterizam a vendagem editorial das revistas semanais, e que se manifestam pela exposição celebrativa do seu processo de construção. De um 
outro modo, querendo compartilhar percursos de escolhas e de definições com seus leitores (que presumivelmente têm acesso a certos implícitos da produção jornalista), reflete sobre o processo do «zizaguear dos jornalistas» na escolha da matéria de capa, algo que implica, como ela reconhece, uma certa racionalidade: "o imperativo da clareza", e que "envolve sempre, devemos admitir, um certo grau de arbitrariedade" (Mariluce Moura, O Imperativo da Clareza, Revista Pesquisa Fapesp, São Paulo, outubro de 2007, edição n.140, p. 7). Não obstante a diferença do foco da publicação, sua estratégia auto-reflexiva chama atenção para a importância que têm as «regras privadas» de um determinado processo produtivo, para orientar as operações de produção de sentido de uma publicação, e sobre as quais se assentam o «contrato» e os efeitos presumidos das próprias estratégias postas em ato.

D) Estratégias de protagonização do leitor - Intensos processos de operações discursivas transformam não só a «topografia» do dispositivo jornalístico, mas as interações que reúnem produtores e receptores de discursos. A lógica dominante prevê uma espécie de diluição entre as fronteiras que os reúne, e mesmo de «zonas de pregnâncias» que os aproximaria, na medida em que os receptores são crescentemente instalados no interior do sistema produtivo, enquanto co-operadores de enunciação. Tais mutações alteram, substancialmente, as identidades desses atores e também as suas posições discursivas, enquanto enunciador e enunciatário, circunstância que por si poderia ser um tema de um incitante estudo. Essa nova economia discursiva estaria produzindo profundas e complexas alterações nas próprias rotinas da cultura e do trabalho do jornalismo, para não dizer nas regras que orientam a codificação da realidade e que passam a ser compartidas com os receptores. Vários fatores tratariam de explicar tais estratégias de inclusão, representando uma nova forma de protagonização do leitor no âmbito do dispositivo, de suas lógicas e de suas regras de produção de sentidos. De modo sintético, enumeramos alguns destes fatores: a chamada convergência tecnológica e seus avatares é usada como princípio de rearticulação das interações entre produtores e receptores de discursos, na medida em que lógicas, processos, produtos e metodologias de produção de mensagens passam gradativamente para as mãos dos receptores. Tais possibilidades de articulação de novas relações entre produção e recepção encontram na autonomia das mídias um fator combinatório para dinamização desses protocolos, uma vez que a autonomia estaria proporcionando ao campo da mídia expandir novas operações interativas com os receptores. Tal compartilhamento estaria reformulando as lógicas até então assentadas em princípios assimétricos e de ordem complementar, uma vez que a competência 
de produção de enunciação dos discursos midiáticos era confiada à sua instância producional. A inclusão do leitor «num jogo a ser jogado» indica uma reformulação no contrato, apontando para um suposto regime de simetrias, e é sinalizada nas próprias operações jornalísticas: “Aqui, você repórter (...) aqui será uma honra ter sua colaboração como nosso repórter” (Época, 09/07/2007). O exemplo citado é apenas um fragmento de uma operação que se intensifica em todas as mídias, nos diferentes gêneros e estratégias discursivas engendrados. Há uma questão de fundo que não pode ser dissimulada e que, de alguma forma representa, o lado mercadológico dessas estratégias, e que diz respeito ao impasse apresentado pelo próprio modelo comunicacional. Se os meios têm autonomia para manejar estratégias interativas estimuladas pelos ventos da convergência, isto não quer dizer que o processo comunicacional se faça através de situações efetivamente de homogeneização. Explicando: sabemos que a qualidade das relações entre produtores e receptores de discursos está caracterizada por inevitáveis desajustes, na medida em que nenhum discurso pode controlar um outro discurso, mesmo que estabeleça, previamente, os efeitos estimados em relação à sua recepção. A mudança do contrato, com a inclusão do receptor no âmbito do próprio dispositivo, significa que ele passa a se constituir num co-gestor de operações de sentido, na medida em que «vem lá de fora, jogar o jogo que se passa aqui dentro». Entretanto, é preciso não esquecer quais são as regras que definem a sua inclusão e que as escolhas de sua produção são determinadas segundo postulados que permanecem no âmbito da lógica do sistema produtivo propriamente dito. Sem dúvida que há na estratégia um sintoma que sinaliza preocupações da produção em evitar que os seus receptores possam vagar para "pontos de fugas», comprometendo o protocolo de sentido e suas metas comerciais e de audiência. Nessas condições, a estratégia visa operar, através daquilo que Luhmann chama de «redutores de complexidade», na medida em que o foco do contrato é, através de supostas diluições de diferenças, educar o receptor para lidar com as lógicas desse sistema de produção-interpretação de discursos.

Depreende-se que a autonomia da midiatização para engendrar contratos aos quais os leitores são submetidos não se realiza de modo exacerbado, uma vez que sua pragmática deve prever a existência do «outro». É por isso que deve incluí-lo como parceiro do contrato, e em conseqüência, contemplá-lo pelos efeitos presumidos da estratégia, que poderia ser chamada de fechamento de circuitos de sentidos. Devemos reconhecer ainda que uma estratégia realizada pelo âmbito produtivo revela a dinamização do dispositivo pela presença de uma nova posição discursiva, a do ombudsman, mas que funciona num regime enunciativo, numa espécie de «duplo vínculo»: ele é instituído pela economia da 
produção organizacional jornalística, mas que deve estar a serviço, ou imaginariamente «insuflado», pelo leitor, cuja inserção na lógica produtiva é situada em meio a outras racionalidades.

Também devemos reconhecer que o estabelecimento desse novo regime de cooperação transforma os anteriores protocolos de interação, uma vez que as operações de sentido passam a ser engendradas em situações de complexas heterogeneidades discursivas e que trazem, com certeza, marcas das experiências cognitivas e culturais dos receptores. De modo imediato, isso nos leva a reconhecer que fronteiras clássicas - reunindo produtores/receptores podem ser diluídas, em favor da emergência de «zonas de pregnâncias» cujo trabalho enunciativo pode apontar para novas «políticas de sentido». Podemos imaginar o que representa para os receptores saber «que podem algo», ao se dar conta que estão inseridos num dispositivo cujos acenos que lhes são dirigidos, os transformam, doravante, em personagens. Também, em que medida os efeitos destas novas intercursividades estariam repercutindo, a partir destas novas regras, sobre a noção de acontecimento?

Por enquanto, para fins de hipóteses que possam gerar debates sobre tais preocupações, e organizar caminhos de investigação, diríamos que o funcionamento do dispositivo nessas condições faz permanecer a defasagem na medida em que o ambiente e a lógica sobre a qual se edifica a analítica da midiatização, trataria apenas de dissimular as diferenças, nas quais se constituem os âmbitos da produção e recepção dos discursos sociais. E, nessas condições, transfere-se para a plataforma da circulação social os desafios e efeitos desses novos processos, aparentemente simetrizados. Alguns exercícios já realizados sobre essas problemáticas sugerem respostas, chamando atenção para o que se definiria como o «efeito de ilusão», produzido por esta interação monitorada pela «analítica» e seus dispositivos. Estariam fomentando a existência de uma interação simetrizante, baseada na ilusão de que «todos podemos nos apresentar na televisão» [de que não haveria sujeitos mais interessantes do que outros], produzindo-se uma espécie de redução da alteridade: tudo vale, todos somos iguais ante as mídias. Já não há término marcado, nenhuma diferença redutível (Imbert, 2003).

\section{BREVE CONCLUSÃO}

O que se pretendeu aqui foi apontar para aspectos do funcionamento do trabalho «analítico» da midiatização (jornalística) a partir das características, lógicas e operações de sentido de sua arquitetura topográfica, de suas motivações, especialmente aquelas que apontam para novos desejos de vínculo com a recepção. O exame de algumas operações chama atenção para a incompletude desta 
«analítica», e que se manifesta, justamente, naquilo que nela é excessivo: sua capacidade de falar, mas segundo estratégias auto-referenciais de suas próprias operações. Resta como caminho a ser percorrido o desafio de trabalhar as complexidades que reúnem o fazer deste «processo interpretativo», principalmente os efeitos da incongruência desta interação explicitada pela permanência das defasagens, mas reconheçamos também, de «zonas de pregnâncias» de sentidos entre produção e recepção. Estudos, com hipóteses encorajadoras, são necessários para que processos sejam reconstituídos pela voz, eficácia e complexidade de outros dispositivos interpretativos, como os que envolvem a investigação acadêmica. No momento, deixo aqui uma espécie de conclusão momentânea $\mathrm{e}$ que certamente será afetada por aproximações de outras leituras sobre o fenômeno: a impossibilidade do processo da midiatização fechar circuitos de sentidos apenas por suas operações de auto-referências, conectando um ponto a outro, faz com que as mídias fiquem se «contemplando» como aparato, dispositivo que, contudo, não dá conta de lidar, de outra forma, com «espaços potenciais» (Belin, 2002) e as suas singularidades. Apesar de autônoma, a midiatização e suas práticas jornalísticas não podem vagar entre as incertezas e as indeterminações desta «realidade de desajuste». Nessas condições, buscam outras formas de vínculos com o «outro», mas assegurando tal relação com a expressão do seu próprio lugar pelas estratégias de suas auto-operações. Temos certeza que estas questões e outras tantas permanecem, por enquanto, assim numa zona insondável, mas também como «índices» a serem investigados.

Um antropólogo, Marc Augé (1998), que vem estudando as simbólicas das sociedades complexas, pergunta-nos em uma de suas obras: como produzir hoje as condições de simbolização do real (no contexto das sociedades midiatizadas)? Ou seja, como atribuímos realidade ao real, através de protocolos de produção de sentidos, quando nada parece não mais sobrar, como objeto para novos esforços de designações? Como conhecer se nada restaria para ser nomeado pelo esforço da criação, da investigação e da própria especulação para ser reconhecido (por aproximações do trabalho da enunciação), diante da inexistência do que poderia ter restado para ser reconhecido, como efeito das operações de auto-referência da midiatização?

Ora, é sabido que o trabalho simbólico é constituído por inevitáveis buracos e por desajustes, sendo a incompletude do seu processo a motivação para o desenvolvimento de novos processos de produção de sentidos. Se a midiatização inscreve suas possibilidades de referir, é preciso lembrar que os sentidos somente podem ser produzidos em «feixes de relações» e não apenas nas fronteiras do próprio território de uma prática social e discursiva. Como vivemos numa ordem das interdiscursividades, esta nos faz lembrar que, 
inevitavelmente, todas as práticas discursivas «abandonam» suas fronteiras próprias, deslocando-se para «zonas de pregnâncias» (Culioli, 1990). São novos ambientes onde se produzem atividades de transformação sobre os quais a midiatização não sabe a priori, as manifestações dos seus efeitos. Atuemos, pois nestas zonas. Talvez, nelas possamos desenvolver outras possibilidades enunciativas, distintas daquelas que experimentamos quando permanecemos na «vigília e no plantão midiáticos». $\mathbf{M}$

\section{REFERÊNCIAS}

AUGÉ, Marc (1998). La guerra de los sueños. Ejercicios de etno-ficción. Barcelona: Gedisa.

BELIN, Emanuel (2002). Une sociologie des espaces potentiels - logique dispositive et expérience ordinaire. Bruxellas: De Boeck \& Larcier.

BRAGA, José Luiz (2006). Sobre "mediatização" como processo interacional de referência. GT Comunicação e Sociabilidade, $15^{\circ}$ Encontro Anual da Compós, Bauru: junho de 2006. CD-ROM.

CHEMAMA, Roland \& VANDERMERSCH, Bernard (2007). Dicionário de Psicanálise. São Leopoldo: Unisinos.

CULIOLI, Antoine (1992). La théorie d'Antoine Culioli - Ouvertures et incidences. Paris: Ophrys.

(1990). Pour une linguistique de l'énonciation - Opérations et représentations. Paris: Ophrys.

FAUSTO NETO, Antônio (2007). Enunciação, auto-referencialidade e incompletude. In: Revista Famecos, $\mathrm{n}^{\circ} 34$, Porto Alegre, dezembro de 2007. (2006). Mutações nos discursos jornalísticos: da "construção da realidade" à "realidade da construção". In: Edição em jornalismo: ensino, teoria e prática. Santa Cruz do Sul: Edunisc.

(2006). Será que ele é? Onde estamos? A midiatização de um "discurso proibido". In: Ícone - Programa de Pós-Graduação em Comunicação. Universidade Federal de Pernambuco. Ano 7, Número 9, dezembro de 2006.

GIDDENS, Anthony (1991). As conseqüências da modernidade. São Paulo: Unesp.

GOMES, Pedro Gilberto (2006). A midiatização, um processo social. In: Filosofia e Ética da Comunicação na Midiatização da Sociedade. São Leopoldo: Unisinos. (2007). O processo de midiatização da sociedade. Paper PPGCOM Unisinos. São Leopoldo, 2007. 
IMBERT, Gerard (2003). El zoo visual - de la télévision espetacular a la télévision especular. Barcelona: Gedisa.

Luhumann, Niklas (2005). A realidade dos meios de comunicação. São Paulo: Paulus. MARTÍN-BARBERO, Jesus (1997). Os métodos: dos meios às mediações. In: Dos meios às mediações. Rio de Janeiro: UFRJ.

MATTA, Maria Cristina (1999). De la cultura masiva a la cultura mediática. In: Diálogos, n.56, Lima: Felafacs.

MELO, Paula Reis (2008). Tensões entre fonte e campo jornalístico: um estudo sobre o agendamento mediático do MST. Tese de doutoramento. Unisinos, São Leopoldo, 2008.

RODRIGUES, Adriano (2000). A autonomização do campo dos media. In: Reflexões sobre o mundo contemporâneo (Raimundo Santana Revan, org.). Teresina: UFPI.

RODRIGUES, Adriano (1999). Experiência, modernidade e campo dos media. www.bocc. ubi.pt. Acessado em 12/02/2008.

SODRÉ, Muniz (2004). Antropológica do espelho. Petrópolis: Vozes.

SODRÉ, Muniz (2006). Eticidade, campo comunicacional e midiatização. In: MORAES, Denis. Sociedade Midiatizada. Mauad, Rio de Janeiro.

VERón, Eliseo (2004). Fragmentos de um tecido. São Leopoldo: Unisinos.

(1998). Semiose de la mediatizacion. In: Mídia e Percepção Social, Conferência Internacional. Instituto Cultural Cândido Mendes. Rio de Janeiro, 18-20/05/1998.

(1997). Semiosis de la ideológica y del poder. In: La mediatizacion - Oficina de publicacion del CBC. Buenos Aires: UBA, 1997. 